\title{
パソコン処理による東洋医学的喨断と 良導絡チャート
}

関西銊众短期大学鍼负学臨床教室

中吉 隆之、王 財源

関西鍼众短期大学銊众学基礎教室

楳田 高士、北村 智、吉備 登

\section{〔はじめに〕}

東洋医学の診断においては望、聞、問、切 の四診から得られる情報は最も重要であり、 これらの情報を総括し、さらに総合的に分析 して「証」が決定されている。しかし、現代 人に比較的理解しやすい西洋医学の解剖・生 理に比べ、独特な解剖・生理観を基礎とした 中医学の八綱弁証・気血津液弁証・臟腑弁証 などは、多くの人たちにとってなかなか理解 しにくい面がある。また、脈診、舌診、腹診 などの習得に関しても、これらをマスターす るには何年もかかるとされ、初学者にとって は取りつきにくい要素がかなり多く存在して いる。

そこで、患者に答えてもらう簡単な問診と 初歩的な脈診、舌診、腹診などにより、これ らの情報をパソコンに入力して統計処理をお こない、東洋医学的診断のうち八綱弁証と臓 腑弁証などが判断できるソフトをクラリス・ ファイルメーカーPro3.0v3を用いて試作し た。

今回は、これらのソフトを用いた実際の弁 証の結果と良導絡測定での興抑判定結果につ いて比較検討をおこなったので報告する。

\section{〔実験方法〕}

対象は、1999年 2 月から 6 月末日までに関 西銊尒短期大学附属診療所銊尒治療部に初診 で来院した患者の男性13名、女性12名の合計 25 名で平均年齢 $56.6 \pm 17.9$ 歳である。主訴は 膝関節痛 6 例が最も多く、腰下肢痛 5 例、肩 背こり 3 例、腰痛 2 例、頭帽感、難聴、疲労、 五十肩、花粉症、咽頭違和感、眼瞼㾏卛、手
根管症候群、視力低下など 1 例ずつと、症状 は多彩であった。(Fig.1)

これらの患者に対して全身にわたる約 60 項 目の問診 (Table1) と痛みの性質、疼痛部 位に関する質問を扔こなった。女性の場合は 月経などに関する質問を加えた。質問に対す る回答は、はい、時々、いいえのいずれかで 答えとし、出来るだけ分かり易い言葉を使用 し、患者を自分の都合が良い方に誘導しない 様に心掛けた。

その回答は、その場でパソコンに直接入力 するのが最も簡単であるが、パソコンがない 時は、印刷した質問表を渡して回答してもら い、それを後でパソコンに入力することも可 能にした。

Fig. 2 は術者が判断する項目で、まず、顔、 爪、唇の色を判断する。また、舌診として、 舌質、舌苔の色、舌下脈絡の怒張、歯痕、芒 刺、裂紋の有無、苔の量、腐脦、潤燥、大き さなどの望診を行う。切診は、脈状診で速さ、 浮沈、虚実、太さ、緊張度、長さ、血流の状 態、調律などを観察した。腹診では、腹部に おける動悸の有無とその部位、しこり、圧痛、 振水音、臍下不仁の有無など、また、按じて 気持ちがいいかどうか、暖めて気持ちがいい かどうかなどを診断してそれらの情報を入力 した。

入力の方法は、例えば、舌質の色では舌質 をクリックすると、その選択項目上に淡白・ 淡紅・紅・綘・紫の色選択の表示が現れるの で、それらから最も適当なものをマウスで選 ぶ。(Fig. 2 では舌質は紫を選択している。) また、脈の速さは 1 分間に 60 回以下を遅、61 

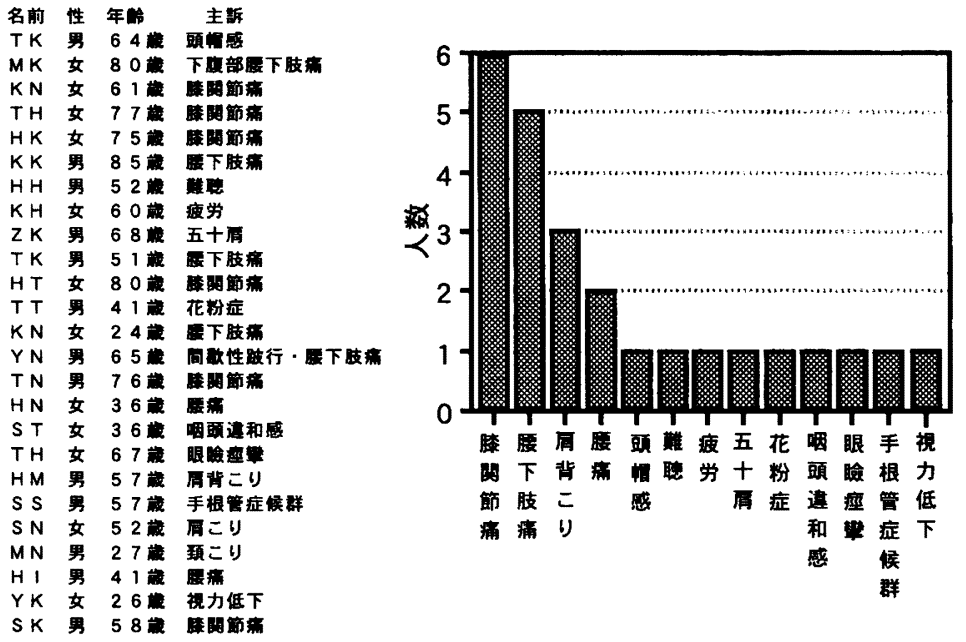

Fig. 1 対象患者の内訳

\begin{tabular}{|c|c|c|c|c|c|c|c|}
\hline 視力低下などの眼の買黨がありますか & Оはい & O時々 & Oいいえ & 口が苦いてすか & Oはい & O赤々 & Oいい \\
\hline 舌炎やもつれなど舌の買常がありますか & Оはい & O時名 & Oいいえ & 手足がしひれたりケイレンすることがありますか & Oはい & O畤么 & Oいい \\
\hline 味覚異常など口居の異常かおりますか & Oはい & O時多 & Oいいえ & めまいをおこしやすいですか & Оはい & O睛々 & Oルいर \\
\hline 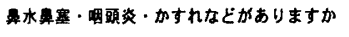 & Oはい & O時々 & Oいいえ. & 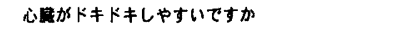 & Оはい & O時々 & Oいい \\
\hline 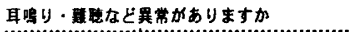 & Оはい & O時々 & OWいג & 物忘れをしやすいでか & Оはい & O時出 & OM \\
\hline 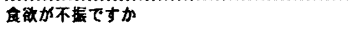 & Oはい & O寺名 & OW6z & 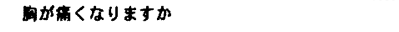 & Oはい & O铣名 & Ow1x \\
\hline ロが渴きますか & Оはい & O時名 & Oいいえ & 意灌を失うことがありますか & Оはい & O锖为 & Oいর \\
\hline 椧たいものかか欺みたいですか & Оはい & O時名 & Oいいえ & 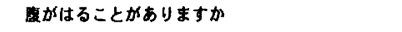 & Оはい & O時々 & Oいえ \\
\hline 暧かいものかか飲みたいですか & Оはい & O时々 & Oいいえ & 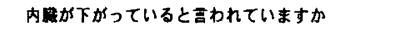 & Оはい & O时多 & Oいর \\
\hline むくんだりすることがありますか & Oはい & O時名 & Oいいえ & 呼吸がしにくいことがありますか & Оはい & O时名 & Oいい: \\
\hline 便球しますか & ○はい & O時 & Oいいえ & よく蚎かでますか & Oは & 等名 & Onis \\
\hline 下解しますか & Оはい & O時々 & Oいいג & よく度がでますか & Оはい & O時及 & Oいい \\
\hline 小便か近いでか & Оはい & O時名 & OWG & 肌があれてカサカサしますか & Оはい & O時尔 & OMU \\
\hline 小便の量が多いですか & ○はい & O時名 & Oいいえ & 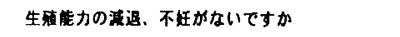 & Оはい & O侍名 & Oいい \\
\hline よく汗をかきますか & Оはい & O时名 & Oいいえ & 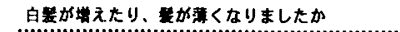 & Оはい & O侍名 & OแU \\
\hline 亶汗をかきますか & $\mathrm{O}+1$ & O時名 & OWbi & 足や后がだるく粪いですか & ÖL & O时等 & Olili \\
\hline 眠りが㳀いてすか & Oはい & O寺出 & Oいいえ & はきけやもどすことがりますか & Оはい & O時々 & Oルい⿱一兀 \\
\hline よく夢をみますか & Oはい & O时出 & 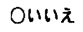 & よく風かつかえますか & Оはい & O畻分 & Oいর \\
\hline のぼせやすいですか & Oはい & O畦为 & OWいえ & 雨が睛ると症状か悪くなりますか & Оはい & O畤々 & Oいいえ \\
\hline 手足が椧たいてすか & Oはい & O時々 & Onwi & 電や骨か强いまうてすか & Oはい & O時々 & Oルর \\
\hline 手足がはてりますか & Oはい & O時么 & ovivin & 同し部位が制すように帮も & OはV & 恧時名 & Onis: \\
\hline 寨さを惑しやすいてすか & Oはい & O時名 & Oいいえ & 症状が同し缡位になく、よく㱛動しますか & Oはい & O時名 & Oルい: \\
\hline 謷かでることがありますか & Oはい & O時々 & OMUえ & ゲッブやおならをするとスッキリしますか & Оはい & O時々 & Oいい \\
\hline 敫れやすいてすか & Оはい & O侍々 & Oいいえ & & & & \\
\hline 何をするにもっつくうでかか & Oł! & O铣々 & OMUх & 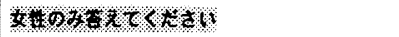 & & & \\
\hline イライラして怒りっ活いてすか & Оはい & O时出 & OWW & 月経加不䫄てすかか & Oはい & OA & Oルル \\
\hline のととになにか端まった䍐しかがりますか & Oはい & O時々 & Oいいえ & 血量が多いてすかか & Oはい & O時名 & Oแ⿻卄二 \\
\hline 頭事がありますか & Oはい & O時々 & Oいいえ & 血且が少ないですか & Oはい & O畦々 & OU⿻і㇒ \\
\hline 勐や撗腹が事むことがありますか & Oはい & O時保 & O川Gえ & 生理庯が强いと思いますか & Oはい & O畦々 & Oแい \\
\hline \multirow[t]{2}{*}{ 出血しやすいですか } & Oはい & O時々 & Oแいえ & 䀧赤色の血の熄がましる & Оはい & O時々 & Onแz \\
\hline & & & & 曼下が多いですか & Oはい & 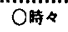 & Öili \\
\hline
\end{tabular}

Table 1 問診の内容

回～65回までを緩、66〜89までを平脈、90以 上を数、110以上を疾とした。

弁証結果は、Fig. 3 に示す通り八綱弁証、 気血津液弁証と臓腑弁証の符合率が\%で表示 される様になっている。この例では表証は 7 項目中の 4 項目が該当し符合率 $57 \%$ 、裏証は
$0 \%$ あ゙あ。寒熱は寒証31\%、熱証では実熱 証が $0 \%$ 、虚熱証が25\%を示し、一応寒証と 判断する。虚実は虚証の気虚が33\%、陽虚が 19\%、血虚が20\%、陰虚が31\%、実証は 0 \% となり、一応虚証と考える。さらに臓腑弁証 では心と大腸が $33 \%$ 、他の蔵腑に比べて多 


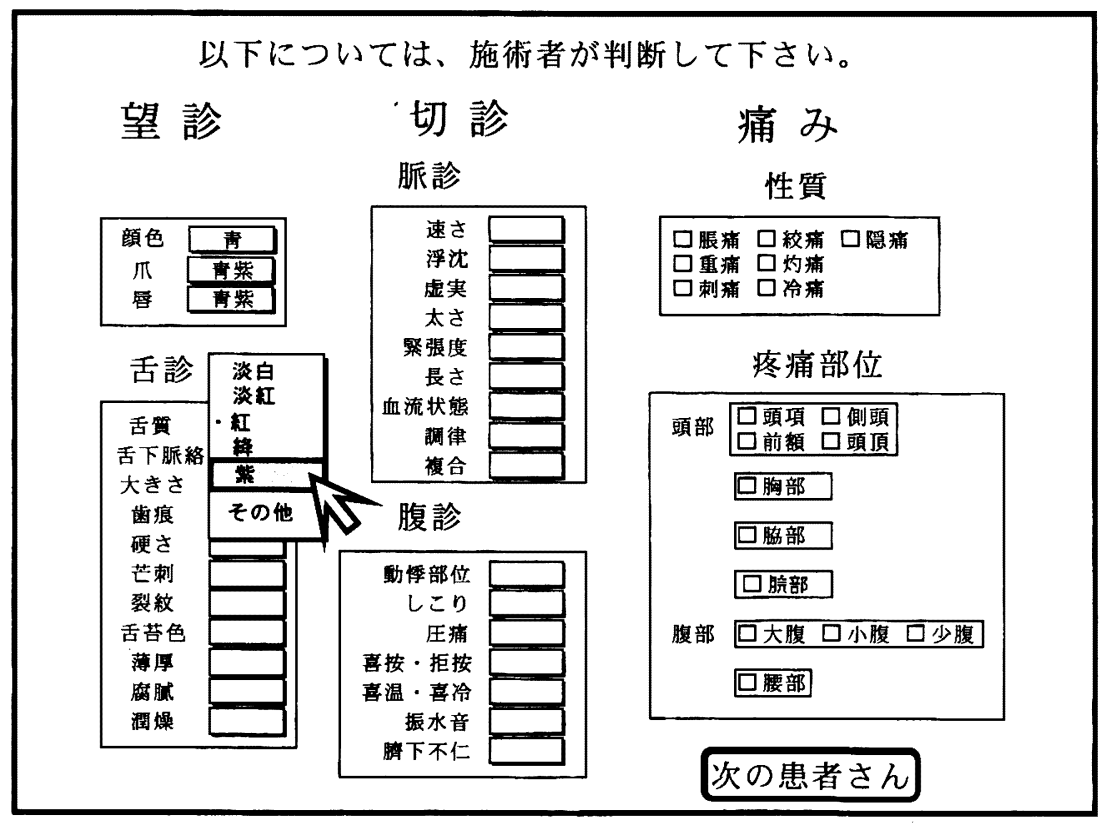

Fig. 2 術者が判断する項目

くなっている。

また、同時にノイロメーターAD 型による 良導絡測定を扢こない、中谷の方法に従って、 良導絡専用カルテに24ケ所の測定部位の皮膚
通電電流量を記入し、臨床的な方法で1.4 cm幅の生理的範囲を、適宜拡大または縮小 して興奮、抑制を示す良導絡を各々 2 から 3 個求めた。

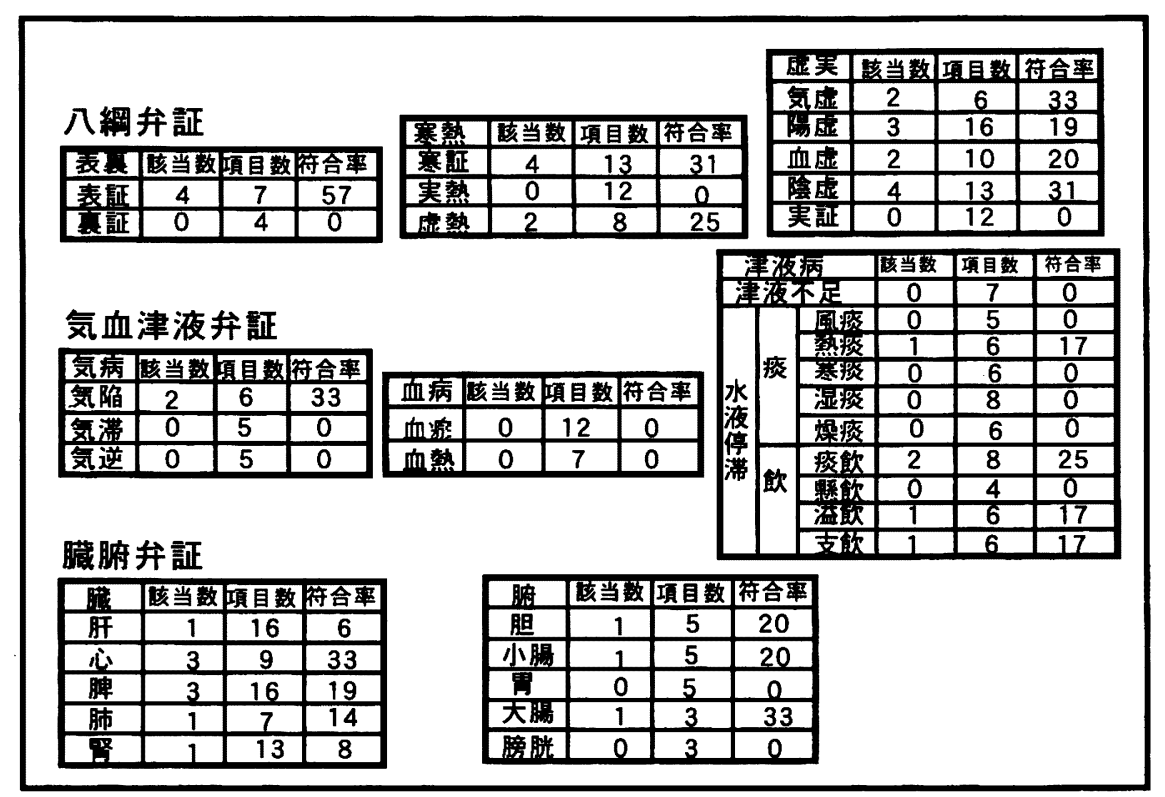

Fig. 3 弁証結果の表示 


\section{〔結果〕}

患者25名の八綱弁証の結果は、Fig. 4 に示 すとおり、病位の深浅を示す表裏では表証 17 名・裏証 8 名となり、疾病の性質を示す寒熱 では寒証17名・熱証 8 名で、うち実熱 2 名・ 虚熱 6 名であった。また、正邪の盛衰を示す 虚実では虚証24名で、そのうち気虚10名・陽 虚 9 名・血虚 2 名・陰虚 3 名あり、実証 1 名 であった。その結果、八綱弁証においては Fig. 5 に示すとおり表寒虚証が12名と最も多 く、表熱虚証 5 名、裏寒虚証 5 名となり、そ の他に裏熱虚証 2 名、裏熱実証が 1 名となっ た。

Fig. 6 に示す臓腑弁証の結果からは第 1 選 択では腎の異常が11名と最も多く、心が 5 名、 肺が 5 名、膀胱が 2 名、胆と脾が 1 名ずつで あった。第 2 選択では腎の異常が 9 名、肺が 6 名、心が 4 名、肝が 4 名、膀胱が 2 名とな り、第 1 選択と第 2 選択を併せると、腎の異 常が20名と最も多く、肺が11名、心が 9 名、 膀胱が 4 名、肝が 4 名、胆と脾が各 1 名とな った。

一方、良導絡測定の異常良導絡の興奮と抑 制の出現頻度はF3 (腎) 抑が15名と最も多 く、F5 (胆) 抑が11名、H5 (三焦) 興が10 名、H1 (肺) 興が 8 名、H3 (心) 抑が 7 名、 F2（肝）興が 7 名、F4（膀胱）抑が 7 名な どが多く認められた。(Fig.7)

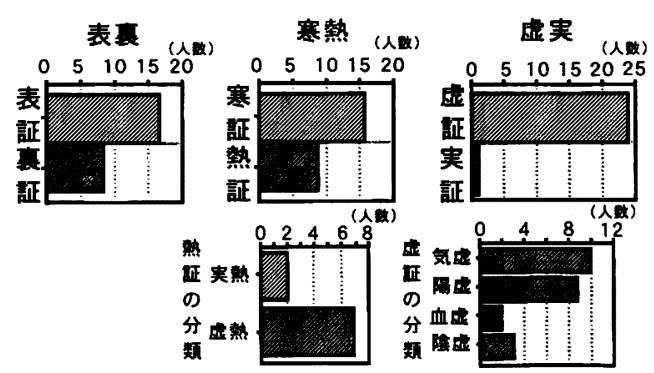

Fig. 4 八網弁柾の結果 1

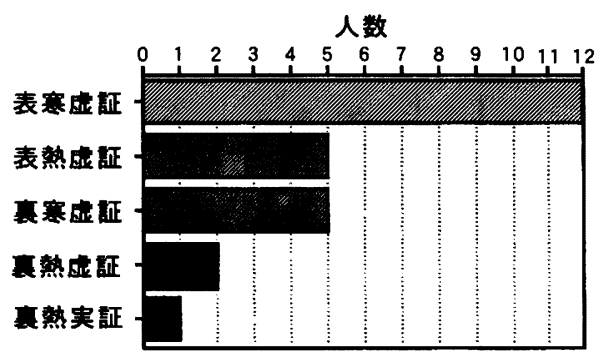

Fig. 5 八絧弁証の結果 2
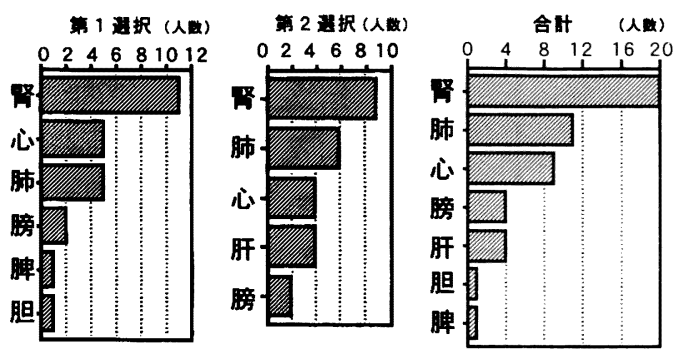

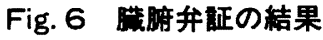

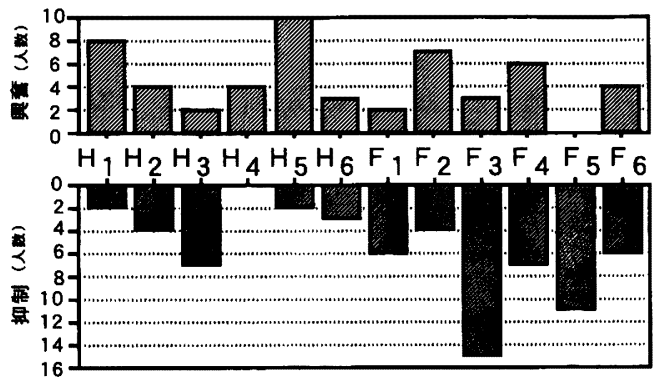

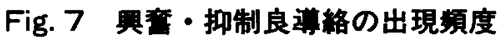

\section{【考察〕}

今回試作した東洋医学的診断システムから 得られた臓腑弁証の結果は、腎の異常で虚証 のものが20名と圧倒的に多く認められ、その なかで良導絡の測定においても F3 (腎) 抑 を示すものが 12 名 $(60 \%)$ 存在した。

中医学の臓腑弁証においては、「腎に実証 なし」といわれるように腎の病証は腎陽虚、 腎陰虚、腎気不固および腎気虚に分けられる。

(Table2) 一方、良導絡の测定は主として 交感神経の機能を測定しているものと考えら れているが、中谷が中谷良導絡研究所のデー 夕から統計的に整理した良導絡症候群表から 
はF3 (腎) の抑では根気がなく疲れやすい $(81 \%)$ 、頭痛 $(65 \%)$ 、足腰が冷える（60 $\%) 、$ 精力減退（15\%）、記憶力減退、耳鳴り、 便通異常、インポテンツなどが現れやすいと されており、中医学における腎虚の症状と類 似している。
これらの各良導絡の測定結果と、今回の東 洋医学的な診断の結果が、比較的よく似た結 果がもたらされたことから、これらの診断方 法には何らかの関連性を持つ可能性が示唆さ れた。

\begin{tabular}{|c|c|c|}
\hline \multicolumn{2}{|r|}{ 病証 } & 症状 \\
\hline \multirow{2}{*}{$\begin{array}{l}\text { 腎 } \\
\text { 陽 } \\
\text { 虚 }\end{array}$} & 腎陽不足 & $\begin{array}{lcc}\text { 婹下肢の泠えだるさ } & \text { 生殖機能の失調 } & \text { 顔色白 } \\
\text { 四肢の冷え・寒がり（インボテンツ、不妊） } & \text { 無気カ }\end{array}$ \\
\hline & 腎虚水泛 & 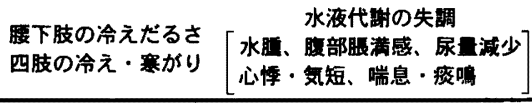 \\
\hline \multicolumn{2}{|r|}{ 腎陰虚 } & 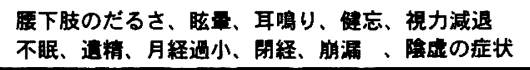 \\
\hline \multicolumn{2}{|c|}{ 腎気不固 } & 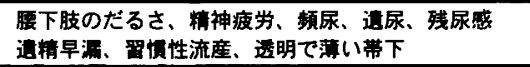 \\
\hline \multicolumn{2}{|c|}{ 腎精不足 } & $\begin{array}{l}\text { 男性の不姡、月経の早期休止、小览の発育不良 } \\
\text { 早期の老化現象 }\end{array}$ \\
\hline
\end{tabular}

Table 2 堅虚証の症状

〔結語〕

患者25名の弁証と良導絡測定の結果を比較 した。

1) 表寒虚証が最も多かった。

2 ）腎の異常が最も多く、肺、心などが多か った。

3 ）良導絡測定ではF3（腎）抑が最も多く、 F5（胆）抑、H5（三焦）興などが多かっ た。

なお、東洋医学においては、病人とのコミ ユニケーションが最も大切なことである。今 回は情報整理のためにコンピューターを使用 したが、そのもとになる情報は、患者さんと の対話とスキンシップによる四診である。こ れからも、この事を充分に認識して患者さん に接したいと思う。今後さらに症例数を増や
して、さらに重み付けなどソフトにも改良を 加えていきたいと考えている。

\section{〔参考文献〕}

1) 日本鍼负良導絡医学会 学術部：良導絡 自 律神経調整療法 基礎編、浪速社、1993.

2 ）監修平馬直樹、兵頭明、路京華、劉公 望：中医学の基礎、東洋学術出版社、1995.

3 ) 内山恵子: 中医診断学ノート、東洋学術出 版社、1996.

4 ) 関口善太：やさしい中医学入門、東洋学術 出版社、 1996.

5 ) 著者 劉燕池、宋天彬、張瑞榎、董連栄 監訳 浅川要: [詳細] 中医基礎理論、東洋 学術出版社、1999第 2 刷

6 ）教科書執筆小委員会: 東洋医学概論、医道 の日本社、1999. 